\title{
MOŻLIWOŚCI WYKORZYSTANIA KORESPONDENCJI MISYJNEJ DO BADAŃ NAD HISTORIĄ WYCHODŹSTWA CHŁOPSKIEGO Z TERENÓW BYŁEJ RZECZYPOSPOLITEJ NA PRZEŁOMIE XIX I XX WIEKU
}

\begin{abstract}
THE POSSIBILITY OF UTILIZING MISSIONARIES' CORRESPONDENCE TO STUDY THE HISTORY OF PEASANT MIGRATION

(FROM THE TERRITORIES OF FORMER POLISH COMMONWEALTH)

AT THE TURN OF THE TWENTIETH CENTURY
\end{abstract}

The article presents new possibilities of research on the history of migration at the turn the 20th century using narrative sources, particularly the correspondence of missionaries. Peasants produced and left behind very few narrative sources, which results in migration historians rarely using them. The author indicates how to use alternative narrative sources produced by people of the Church to study the history of migration, in particular emigration from the territories of the former Polish Commonwealth.

Keywords: emigrating peasants, missionaries, narrative sources

Słowa kluczowe: emigracja chłopska, misjonarze, źródła narracyjne

Pionierami zamorskiego wychodźstwa z terenów byłej Rzeczypospolitej byli mieszkańcy zaboru pruskiego' ${ }^{1}$. Emigracja chłopska o charakterze masowym z terenów

D. Praszałowicz, K.A. Makowski, A.A. Zięba, Mechanizmy zamorskich migracji tańcuchowych wXIX wieku: Polacy, Niemcy, Żydzi, Rusini - zarys problemu, Kraków 2004, s. 123-124. 
Galicji $^{2}$ i zaboru rosyjskiego ${ }^{3}$ zaczęła się nieco później, mniej więcej w drugiej połowie XIX stulecia. Wraz z upływem kolejnych lat fala emigracyjna wzrastała, zaś jej charakter zaczął się zmieniać. Początkowo dominowała migracja sezonowa do krajów europejskich, z czasem pobyty trwały coraz dłużej, a kierunki podróży były coraz bardziej odległe.

Jak wynika z badań Haliny Jankowskiej, ponad 90\% osób, które emigrowały, pochodziło z terenów wiejskich ${ }^{4}$. Problemy ekonomiczno-polityczne powodowały, że włościanie opuszczali swoje rodzinne strony i udawali się za granicę bez względu na to, z którego zaboru pochodzili. W ten sposób chcieli pomóc swojej rodzinie, bliskim lub po prostu zacząć zupełnie nowe życie na obczyźnies. Dlatego po dotarciu do punktu docelowego nie zawsze zajmowali się rolnictwem. Każda emigracja - czy to zamorska, czy kontynentalna - miała swoją charakterystykę, dlatego o ile w Brazylii ${ }^{6}$ i w Bośni chłopi zajmowali się głównie karczowaniem puszczy i uprawą roli ${ }^{7}$, o tyle już w USA musieli być bardziej elastyczni pod względem wykonywanej pracy ${ }^{8}$. Część osób pochodzenia chłopskiego po dotarciu do wielkich miast Ameryki Północnej - Chicago czy Nowego Jorku - zasilała szeregi rosnącej populacji mas robotniczych?

Chłopi, chociaż udawali się za granicę, starali się utrzymywać więź z pozostałymi w miejscu, z którego wyemigrowali, krewnymi oraz znajomymi. Zwłaszcza na początku pobytu z dala od domu utrzymywanie kontaktu z bliskimi było bardzo ważne. Jak zauważa Florian Znaniecki, dopiero po pewnym czasie dochodziło do erozji relacji między krewnymi ${ }^{10}$. Jedyną formą komunikowania się chłopów z bliskimi była korespondencja, która miała trafiać nie tylko do pojedynczej osoby, ale całej rodziny, gdyż autorzy listów często wskazywali, by były one czytane wszystkim mieszkańcom domu ${ }^{11}$. Jednak korespondencja

2 J. Mazurek, Piórem i czynem. Kazimierz Warchatowski (1872-1943) - pionier osadnictwa polskiego w Brazylii i Peru, Warszawa 2013, s. 41-42.

3 J. Mazurek, Kraj a emigracja, Warszawa 2006, s. 27-30.

4 H. Jankowska, J. Spustek, Wychodźstwo polskie w Stanach Zjednoczonych, [w:] Pamiętniki emigrantów, t. 1: Stany Zjednoczone, red. J. D z i e m b ow sk a, Warszawa 1977, s. 31.

5 A. Pilch, Emigracja z ziem zaboru austriackiego (od potowy XIX w. do 1918 r.), [w:] Emigracja z ziem polskich w czasach nowożytnych i najnowszych, red. id e m, Warszawa 1984, s. 254-256.

6 M. Michalik-Sztumska, Wychodźstwo polskie w Brazylii. Stan badań nad zagadnieniem, „Prace Naukowe Akademii im. Jana Długosza w Częstochowie. Zeszyty Historyczne” 2010, z. 11, s. 326.

7 T.J. Lis, Polskie osadnictwo i duchowieństwo w Bośni i Hercegowinie od 1894 do 1920 roku, Toruń 2014, s. 113.

8 Do USA udawali się głównie młodzi mężczyźni, którzy potem ewentualnie ściągali rodzinę lub zakładali ją na miejscu. W.I. Tho m a s, F. Zn a n i c cki, Chtop polski w Europie i Ameryce, t. 1, Warszawa 1976, s. 12.

$9 \quad$ Ibidem, s. 14.

10 O badaniach nad emigracją chłopską prowadzonych przez Floriana Znanieckiego zob. A. Wieruszewska, Dzieto „Chtop polski w Europie i Ameryce”, czyli o pożytkach czytania klasyków, „Studia Migracyjne - Przegląd Polonijny” 2012, t. 38, nr 2, s. 5-24.

11 B. Bacz ko, Pisać listy z Hameryki, „Zeszyty Historyczne” 1982, t. 61, s. 55. 
w przypadku włościan nastręczała wiele problemów, gdyż chłopi, zwłaszcza z zaborów austriackiego i przede wszystkim rosyjskiego, byli w większości analfabetami ${ }^{12}$.

Skalę problemu najlepiej obrazują statystyki. Jednakże dane przywołane przez Eugeniusza Römera w jego Tablicach oddają jedynie część prawdy, gdyż liczby te tyczą się całej populacji, przez co mieszkańcy większych miast zawyżają odsetek ludzi piśmiennych na rzecz wsi. Dlatego też, jeśli zostało podane, że w 1897 r. w guberni lubelskiej na 1000 mieszkańców liczba analfabetów wynosiła 690 osób, należy założyć, że na wsi odsetek ten był jeszcze większy ${ }^{13}$. Z kolei Bronisław Jaśkiewicz twierdzi, że chociaż liczba osób niepiśmiennych w ciągu niespełna 25 lat spadła o prawie 20\%, to i tak w 1900 r. mieliśmy w Galicji prawie $60 \%$ osób, które były analfabetami ${ }^{14}$. Jeszcze gorzej wyglądała sytuacja na wschodnich rubieżach byłej Rzeczypospolitej, gdzie odsetek analfabetów w zaborze rosyjskim był większy nawet niż w Galicji15. Jak obliczył na początku XX w. Antonii Lange zajmujący się problemem analfabetyzmu w Galicji i Kraju Nadwiślańskim, o ile w zaborze austriackim na nieco ponad $7 \mathrm{mln}$ obywateli niepiśmiennych było ponad $3 \mathrm{mln}$, o tyle w zaborze rosyjskim na $10 \mathrm{mln}$ mieszkańców aż $8 \mathrm{mln}$ nie potrafiło czytać i pisać $(!)^{16}$.

Oczywiście, nawet jeśli weźmiemy pod uwagę, że powyższe statystyki mogą nieco na-

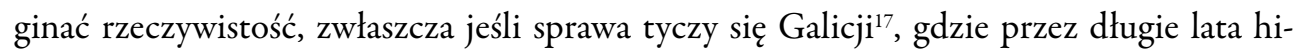
storiografia zdecydowanie przesadzała z "galicyjską biedą"18, to problem braku znajomości pisania i czytania wśród chłopów był bezsprzecznie ogromny. Przykładowo w 1881 r. w na poły wiejskim ośrodku miejskim ${ }^{19}$ Limanowa, mającym status siedziby powiatu, niespełna $5 \%$ mieszkańców potrafiło pisać i czytać! ${ }^{20} \mathrm{O}$ ile analfabetyzm nie przeszkadzal jednak

12 M. Baczkowski, Analfabetyzm $w$ Galicji $w$ dobie konstytucyjnej, [w:] Naród - Państwo. Europa Srodkowa w XIX i XX wieku. Studia ofiarowane Michatowi Putaskiemu w pię́dziesięciolecie pracy naukowej, red. A. Patek, W. Roj ek, Kraków 2006, s. 97-113.

13 E. Römer, Rocznik Polski. Tablice statystyczne, Kraków 1917, s. 56.

14 B. Jaśkiewicz, Dziatalność Towarzystw Oświatowych $w$ Tarnowie w latach autonomii galicyjskiej, „Rozprawy z Dziejów Oświaty” 1974, t. 17, s. 106.

15 E. Römer, op.cit.

16 A. Lange, Analfabetyzm i walka z ciemnota w Królestwie Polskim, Warszawa 1906, s. 12.

17 M. Baczkowski, op. cit., s. 98.

18 M. Śliwa, Nędza galicyjska. Mit i rzeczywistość, [w:] Galicja i jej dziedzictwo, t. 1: Historia i polityka, red. W. B o nusiak, J. B u sz ko, Rzeszów 1994, s. 145-155; K. B rońsk i, Problem zacofania gospodarczego Galicji. Mity i fakty, [w:] Historia gospodarcza i historia myśli ekonomicznej a teoria ekonomii. Problemy metodologiczne, red. J. Skod la rski, Łódź 2008, s. 67-82. Por. A. Ch w al b a, Czy Galicji sukces byt pisany? Cywilizacja przemystowa 1880-1914, [w:] Kraków i Galicja wobec przemian cywilizacyjnych (1866-1914), Kraków 2011, s. 25-30; M. Men z, Recepcja Galicji we wspótczesnej historiografiipolskiej, „Sensus Historiae” 2014 , t. 16, nr 3, s. 75-101.

19 O wiejskim charakterze małych miast w Galicji zob. J. Hoff, Spoteczność matego miasta galicyjskiego w dobie autonomicznej, Rzeszów 1992.

20 Ludność Galicji, „Ekonomista” 1881, nr 46 (15 XI), s. 10. 
w życiu codziennym na wsi, o tyle gdy chłop udawał się do innego kraju lub nawet na inny kontynent, słowo pisane pozostawało jedyną formą kontaktu z jego krewnymi ${ }^{21}$.

\section{Chłopskie źródła narracyjne}

Trudno więc, wobec powyższego, oczekiwać znacznej liczby korespondencji z tego okresu wytworzonej przez samych chłopów ${ }^{22}$. Jest to szczególnie bolesne dla historyka, gdyż listy ${ }^{23}$ stanowią niepowtarzalne świadectwo minionych czasów ${ }^{24}$. Niemałą rewolucję w badaniach nad wychodźstwem chłopskim wywołała praca pod redakcją Witolda Kuli, Listy emigrantów z Brazylii i Stanów Zjednoczonych 1890-189125, wydana w PRL. Znalazło się w niej prawie 400 listów, których autorami byli chłopi. Jest to największy zbiór listów chłopskich wydanych w jednorazowej publikacji. Paradoks historii polega na tym, że były one autorstwa wychodźców, którzy pochodzili z zaboru rosyjskiego, mającego, jak wskazałem powyżej, największy odsetek analfabetów. Źródła te zachowały się tylko dlatego, że carska cenzura nie dostarczyła ich do adresatów i je zarekwirowała ${ }^{26}$. Zdaniem niektórych na-

21 M.Ja szczyń ska, Korespondencja emigrantów jako źródto do badań nad dziejami emigracji, [w:] Emigracja iśrodowiska polonijne. Archiwa i archiwalia, red. A. Ku le ck a, Warszawa 2013, s. 36.

22 Jeśli chodzi o późniejszy okres, zwłaszcza PRL, mamy dość dużo listów przedstawicieli niższych warstw społecznych, takich jak robotnicy czy chłopi. Zob. A.M. Adamus, Problemy wsi w Polsce $w$ latach 1956-1980 w świetle listów do wtadz centralnych, Warszawa 2017; S. S tęp ka, Wieś i rolnictwo w świetle materiatów Biura Listów i Inspekcji KC PZPR (1970-1989), „Roczniki Dziejów Ruchu Ludowego” 2008, nr 35, s. 293-308; K. Zawadka, „Obywatelu Sekretarzu...”. Korespondencja obywateli z lubelskim KW PZPR w latach 1949-1953, „Teka Komisji Historycznej” 2009, t. 6, s. 127-138.

23 Stanisław Kościałkowski zaproponował, by korespondencję sklasyfikować jako zupełnie odrębny gatunek źródeł epistolarnych. Id e m, Historyka - wstęp do studiów historycznych, Londyn 1954, s. 54 . Zgodził się z nim Stefan Krakowski, który podjął próbę zdefiniowania listu jako źródła, wyodrębniając jego indywidualne cechy źródłowe, takie jak: cel treści źródła, stosunek nadawca - adresat, a także pojęć odległości i dystansu. Id e m, List jako źródto historyczne. Uwagi w sprawie definicji i kategoryzacji, „Sprawozdania z Czynności i Posiedzeń Naukowych Łódzkiego Towarzystwa Naukowego" R. 40, 1986, nr 8, s. 6.

24 K. Gajewski, $Z$ poetyki listu chtopskiego do wtadzy. Od stalinizmu do matej stabilizacji, „Rocznik Antropologii Historii” R. 6, 2016, s. 206-207. Najlepszą pracą dotyczącą tego zagadnienia jest monografia literaturoznawczyni z 1937 r., której reedycja pojawiła się w 2006 r.: S. Skwarczyńsk a, Teoria listu, Białystok 2006, oprac. E. Feliksiak, M. Leś, s. 24-26. Por. S. Krakowski, op. cit. O liście jako formie komunikowania w XIX w.: Sztuka pisania. O liście polskim w wieku XIX, red. J. Sztachelska, E. Dąbrowicz, Białystok 2000. Jednak zagranicą, szczególnie w krajach anglosaskich, list jako źródło historyczne ma swoją bogatą bibliografię - zob. The Book of Abigail and John: Selected Letters of the Adams Family, 1762-1784, ed. L.H. But terfield, M. Frie dla en de r, M-J. Klin e, Cambridge 1974; T. Dublin, Farm to Factory: Women's Letters, 1830-1860, New York 1993; J.G. Alt ma n, Epistolarity: Approaches to a Form, Ohio 1992.

25 S. Ki en i ew ic z, Listy, które nie doszty do celu, „Nowe Książki” 1974, nr 24, s. 31.

26 W. Kula, N. Assorodobraj-Kula, M. Kula, Listy emigrantów z Brazylii i Stanów Zjednoczonych 1890-1891, Warszawa 1973, s. 5-7. 
ukowców źródło to jest cenniejsze niż wcześniej znane pamiętniki czy wspomnienia, gdyż lepiej nadaje się do badania świadomości autorów ${ }^{27}$. Zresztą już w XIX w. przywiązywano uwagę do chłopskich listów jako źródła, które najlepiej obrazuje sytuację wychodźców ${ }^{28}$.

Podobną rolę co list odgrywa dla historyka źródło, takie jak pamiętnik - jednak pamiętniki, z identycznych powodów co korespondencja, również stanowią rzadkość wśród chłopów, szczególnie tych przebywających na emigracji. Do połowy XIX w. istniało bardzo niewiele pamiętników pisanych przez włościan, do tego ani jeden nie dotyczył życia na obczyźnie ${ }^{29}$. W kolejnych latach liczba dzienników i pamiętników rosła, podobnie jak liczba wykształconych chłopskich synów ${ }^{30}$. Na próżno wśród tych źródeł szukać jednak wspomnień osób, które udawały się na emigrację zarobkową ${ }^{31}$. Tego typu źródła pojawiły się dopiero pod koniec międzywojnia, kiedy Instytut Gospodarstwa Społecznego ogłosił konkurs na pamiętniki emigrantów. Wówczas zgłosiło się kilkaset osób, w większości chłopów wychodźców, którzy przysłali do Warszawy swoje spisane wspomnienia ${ }^{32}$. Część z nadesłanych prac uległa niestety zniszczeniu w czasie wojny ${ }^{33}$. Niemniej jednak waga tego źródła jest trudna do przecenienia, mimo że wspomnienia zostały spisane w konkretnym, konkursowym celu, a nie, jak to zwykle bywa, z indywidualnej potrzeby piszącego.

Nieliczne materiały narracyjne wytworzone przez emigrantów najpierw stanowiły obiekt badań socjologów, dopiero później zajęli się nimi przedstawiciele innych dyscyplin, w tym historycy ${ }^{34}$. Nie czas i miejsce, by omawiać to zagadnienie, jednak z kronikarskiego obowiązku należy odnotować cytowane już dzieło Floriana Znanieckiego i Wiliama I. Thomasa, oparte w głównej mierze na korespondencji i pamiętnikach emigrantów pochodzenia chłopskiego ${ }^{35}$ - autorzy ci, posługując się tego rodzaju źródłem, wydali liczącą sobie kilka tomów monografię, stanowiącą jedną z najdoskonalszych prób całościowego opisu problematyki emigracji chłopskiej z terenów byłej Rzeczypospolitej na przełomie XIX i XX w. ${ }^{36}$

27 H. Brodowska-Kubicz, $Z$ listów chtopów emigrantów, „Annales Universitstis Mariae Curie-Skłodowska. Sectio K. Politologia" 1999, t. 6, s. 95.

28 Zob. Listy z Brazylii przez wychodźców do rodzin pisane, red. A. Po to cki, Warszawa 1891.

${ }^{29}$ K. Dunin-Wąsowicz, Świadomość narodowa chtopów $w$ świetle pamiętników w okresie powstań narodowowyzwoleńczych, „Acta Universitatis Lodziensis - Folia Historica” 1992, nr 45, s. 87-88.

30 A.K. B a nach, Kariery zawodowe studentów Uniwersytetu Jagiellońskiego pochodzenia chtopskiego z lat 1860/1861-1917/1918, Kraków 2009, s. 8.

31 Wojciech Darasz był zarówno chłopskim synem, jak i emigrantem, jednak jego wychodźstwo do Francji było spowodowane nie względami ekonomicznymi, a politycznymi.

32 Pamiętniki emigrantów, cz. 1, red. S. S te m pow ski, Warszawa 1939, s. XXII.

33 T. Szturm de Sztre m, Instytut Gospodarstwa Spotecznego 1920-1944, Warszawa 1959, s. 135.

34 B. Szatur-Jaworska, Analiza pamiętników jako metoda badawcza w nauce o polityce spotecznej, „Problemy Polityki Społecznej. Studia i Dyskusje” 2001, nr 3, s. 83.

35 Zob. W.I. Thomas, F. Zn an iecki, op. cit., t. 1-5, Warszawa 1976.

36 M. Woś, Salezjański system wychowania a socjologia wychowania Floriana Znanieckiego, „Seminarae” 2015, nr 21, s. 532-534. 
Źródła narracyjne, nazywane też osobistymi, nie tylko mogą pomóc, ale są wręcz konieczne, jeśli chcemy szerzej spojrzeć na problem mentalności chłopów przebywających na emigracji. Problemem jest jednak niewielka liczba tego typu materiału źródłowego ${ }^{37}$. Jak wykazałem powyżej, wpływ na to ma kilka czynników. Przede wszystkim sami twórcy źródła, czyli niepiśmienni chłopi. Brak znajomości czytania i pisania skutecznie uniemożliwiał pisanie listów (te jednak czasami dyktowano co bardziej wykształconym kolegom ${ }^{38}$ ), nie wspominając o pamiętnikach. Drugą istotną sprawą, mającą dla nas znaczenie, jest stan zachowania tego typu materiałów. Arystokracja, inteligencja, a nawet mieszczaństwo dbało o spuściznę po przodkach, dlatego zarówno listy, jak i prywatne notatki ojców oraz dziadów zachowały się w niewspółmiernie większej liczbie, niż miało to miejsce w przypadku chłopów. Wpływał na to nie tylko stan świadomości włościan, ale również ich warunki mieszkaniowe, które nie służyły zachowaniu łatwo niszczejących kartek papieru. Ponadto, o ile w przypadku wyżej wymienionych grup społecznych źródła narracyjne miały mniejsze lub większe znaczenie nie tylko sentymentalne, ale także polityczne czy naukowe, o tyle w przypadku chłopów mówimy jedynie o dokumentach, które z perspektywy ówczesnych osób miały wyłącznie sentymentalny charakter. Nie było więc potrzeby ich przechowywania dla kolejnych pokoleń. Zwłaszcza że wśród chłopstwa pamięć o przodkach była zachowywana przede wszystkim w formie ustnej, gdyż tradycja oralna była charakterystyczną cechą niepiśmiennej wsi ${ }^{39}$.

Historyk zajmujący się problemem emigracji chłopskiej ma więc do dyspozycji stosunkowo niewielką liczbę źródeł takich jak listy czy pamiętniki, biorąc pod uwagę fakt, jak powszechny charakter miało opisywane zjawisko ${ }^{40}$. Niektórzy badacze starali się wyłowić korespondencję włościańską z prasy ludowej, do której pisywali listy chłopscy emigranci ${ }^{41}$. Jednak sytuacja ta znów implikuje pewne problemy, ponieważ list pisany z myślą o publikacji w gazecie jest czymś zupełnie innym niż list adresowany do konkretnej osoby, o czym będzie mowa w dalszej części artykułu. Dlatego też naukowiec chcący zajmować się historią emigracji chłopskiej w większości jest skazany na źródła innego rodzaju, które jednak w żaden sposób nie są w stanie dać odpowiedzi na wiele pytań związanych z życiem codziennym emigrantów.

37 O wykorzystaniu listów emigrantów do badań nad wychodźstwem zob. A. B ro że k, Listy emigrantów jako źódto w tradycji i wspótczesności polskich nauk spotecznych, [w:] Dziedzictwo Witolda Kuli, Warszawa 1990, s. 33-38.

38 H. Brodowska-Kubicz, op. cit., s. 95-96.

39 A. Mlekodaj, Wieś i gwara $w$ dobie rekonfiguracji kultury (na przyktadzie Podhala), „Wieś i Gwara” 2016, t. 8, s. 19-20.

40 Z terenów byłej Rzeczypospolitej od połowy XIX w. do I wojny światowej wyemigrowało do $10 \mathrm{mln}$ osób. Więcej na ten temat zob. A. Wa la s ze k, Migracje Europejczyków. 1650-1914, Kraków 2007.

41 A. Pasterniak, Listy emigrantów do "Przyjaciela Ludu”, „Wieńca i Pszczótki”, „Zarania”, "Piasta”, „Wyzwolenia” w latach 1899-1938, wybór i oprac. A. Past e r n i ak, Rzeszów 1994. 
Dlatego też większość monografii dotyczących wychodźstwa opiera się na prasie emigracyjnej ${ }^{42}$ i przede wszystkim źródłach statystycznych ${ }^{43}$. Autorzy operują więc liczbami, które co prawda dają pewien ogólny ogląd czy to na sytuację materialną wychodźców, czy szerzej rozwój ich społeczności w nowej rzeczywistości, jednak jest to tylko „jedna strona medalu”. Opisywanie emigracji wyłącznie przez pryzmat statystyk wydaje się niepełne, gdyż w ten sposób autor pozbawia czytelnika możliwości przyglądnięcia się opisywanym zagadnieniom z perspektywy konkretnego człowieka, który wyemigrował. Co więc jednak może zrobić dana osoba, by przybliżyć życie codzienne emigranta, skoro on sam, prócz liczby w spisie, nie pozostawił po sobie wiele więcej śladów? Historyk, widząc niemożność skorzystania ze źródeł bezpośrednio wytworzonych przez chłopa, a więc w tym przypadku listów czy pamiętników, jest zmuszony sięgnąć po podobnego rodzaju materiał, gdyż - jak wspomniałem - ani prasa, ani statystyki nie stanowią odpowiedniego „zamiennika”, z którego można czerpać informacje o życiu codziennym emigracji. Musi on więc sięgnąć po źródła powstałe niejako pośrednio. Ich autorami powinny być osoby z kręgu emigrantów. Mamy więc albo nieliczne teksty dziennikarskie, co jakiś czas pojawiające się w prasie ${ }^{44}$, albo pamiętniki z podróży $y^{45}$ lub też wreszcie źródła najbardziej mnie interesujące - materiały powstałe za sprawą działalności duchownych.

Chłop z terenów Galicji, który udawał się na emigrację, w większości (nie licząc Rusinów będących unitami) był rzymskim katolikiem. Religia była dlań bardzo istotnym elementem życia. Jak pisze Józef Bakalarz:

Opuszczając dom rodzinny emigrant zostawiał w nim zwykle cały dorobek, a brał ze sobą tylko obraz Matki Bożej oraz książkę do nabożeństwa. Modlitewnik był najczęściej spotykaną książką, która „szła” za polskim emigrantem. Był bowiem czymś więcej niż książką czy nawet główną pozycją w całym ruchomym inwentarzu. Należał do atrybutów ściśle związanych z osobą i jej dotychczasowym życiem ${ }^{46}$.

42 A. Paczkowski, Prasa polonijna w latach 1870-1939. Zarys problematyki, Warszawa 1977.

43 Metody ilościowe w badaniach nad migracjami są stosowane w bardzo wielu dyscyplinach, które zajmują się tym problemem. Problemy dziejów Polonii, red. M.M. D rozd ow ski, Warszawa 1979; E. Jaźw ińska, Metody ilościowe w badaniach nad migracjami narodowymi, „Prace Migracyjne” 2000, nr 36, s. 1-36.

44 Zob. Listy z Brazylii Adolfa Dygasińskiego, specjalnego delegata "Kuriera Warszawskiego”, Warszawa 1891; R. D mow ski, Z Parany, ,Przegląd Wszechpolski” 1900, nr 2, s. 109-121; nr 3, s. 172-182; nr 6, s. 359-375 .

45 A. Hem pl, Polacy w Brazylii przez Antoniego Hempla cztonka wyprawy naukowej dra J. Siemiradzkiego do Brazylii i Argentyny, Lwów 1893; T. Chrostow ski, Parana. Wspomnienia z podróży w roku 1914, Poznań 1922; S. Kłobukowski, Wspomnienia z podróży po Brazylii, Argentynie, Paragwaju, Patagonii i Ziemi Ognistej, Lwów 1899; idem, Wycieczka do Parany (stanu Rzeczypospolitej Brazylii). Dziennik podróży, Lwów 1909.

46 J. B a ka la r z, Polskie modlitewniki na emigracji, „Studia Polonijne” 1981, t. 4, s. 215. 
Dlatego po dotarciu na miejsce przeznaczenia jedną z podstawowych potrzeb, jakie komunikowali emigranci, był dostęp do duchownych, najlepiej mówiących po polsku, tak by chłopi mogli posłuchać „słowa Bożego” w znanym sobie językư ${ }^{47}$. Gdy tylko wychodźstwo nabrało charakteru masowego, sytuacją zainteresował się Kościół zarówno diecezjalny $y^{48}$, jak i zakonny ${ }^{49}$. Oczywiście nie brakowało krytycznych uwag kierowanych i z ambon, i z pism katolickich pod adresem ruchu emigracyjnego ${ }^{50}$, niemniej jednak był on na tyle duży, że upomnienia nic nie dały. Kościół musiał więc włączyć się w ten proces, gdyż inaczej mógłby stracić wielu wiernych, którzy z powodu braku duchownych mogliby się zlaicyzować lub zostać przejęci przez inną wspólnotę religijną. Szczególną opiekę nad polskimi chłopami zagranicą roztoczył krakowski bp Adam Stefan Sapieha, który osobiście interweniował w sprawie nadużyć, jakich dopuszczały się osoby pośredniczące w transporcie tych, którzy pragnęli dostać się do innych krajów ${ }^{51}$.

Początkowo był to kler świecki, a następnie zakonny, często - jak zmartwychwstańcy i werbiści - przygotowywany do pełnienia funkcji duszpasterskich w czasie misjij ${ }^{2}$. Kiedy ruch misyjny na dobre rozpoczął swoją działalność, duchowni towarzyszyli swoim wiernym często już na etapie podróży. Wraz z nimi wypływali z portów w Bremie, Hamburgu czy Trieście, aż po cel podróży, którym był jeden z zamorskich portów ${ }^{53}$. Polscy księża i zakonnicy byli bardzo ważnymi postaciami. Ich obecność doceniali zarówno rodacy, jak i miejscowi hierarchowie kościelni, którzy cenili sobie zaangażowanie w pracę duszpasterską polskich duchownych. Szczególnie na pomoc z ich strony liczyli biskupi ze Stanów Zjednoczonych i Brazylii. Swoje misje do tych krajów organizowały więc, oprócz kleru świeckiego, także zgromadzenia zakonne: zmartwychwstańcy, franciszkanie, felicjanki, werbiści, wincentyni itd. ${ }^{54}$

Każdy duchowny, który został zobligowany przez swoje zgromadzenie lub przez biskupa do podjęcia misji wśród Polonii, utrzymywał listowną łączność ze swoim przełożonym. Reprezentatywność jest tu więc zdecydowanie większa niż w przypadku chłopskich listów,

47 Archiwum Kurii Metropolitalnej w Krakowie, Teki Sapieżyńskie [dalej: AKMK, TS], List kolonistów z Grabaśnicy, 21.05.1912, sygn. XX/12; J. M a zu r ek, Kraj a emigracja, s. 78-79.

48 S. Pi e ch, Duchowieństwo a masowe migracje zarobkowe w diecezji tarnowskiej 1876-1914, „Chrześcijanin w Świecie" R. 16, 1984, nr 2, s. 48-66.

49 T. D w or ecki, Zmagania polonijne w Brazylii, t. 1: Polscy werbiści 1900-1978, Warszawa 1980, s. 7-8.

50 E. Walewander, Duszpasterstwo polskie w Ameryce Eacinskiej. Przyczynek do bibliografii, [w:] Rola duszpasterstwa polskiego w organizacji spoteczności lokalnych w Ameryce Eacińskiej, red. M. Mal in o w sk i, Warszawa 1999, s. 45.

51 AKMK, TS, sygn. IV/77-93.

52 J. Mazurek, Kraj a emigracja, s. 79-80.

53 Missye polskie w Ameryce, „Missye Katolickie” R. 2, 1883, nr 9, s. 237.

54 P. Ta r a s, Problemy duszpasterstwa polonijnego na przyktadzie sytuacji w USA, „Studia Polonijne” 1977, t. 2, s. 188; Z. Malczew ski, W trosce nie tylko o rodaków. Polscy misjonarze w Brazylii, Curtiba 2001, s. 37-39. 
gdyż pisali zasadniczo wszyscy misjonarze (jedni częściej, inni rzadziej), nie wszystkie jednak listy zachowały się w całościs5. Misjonarz miał nie tylko obowiązek, ale również często realną potrzebę kontaktu z krajem i swoimi współbraćmi, przełożonymi. Chociaż przebywał daleko od bliskich mu osób i miejsc, chciał choćby w symboliczny sposób, a więc korespondencyjnie, zachować więź, jaka go z nimi łączyła. Także oni chcieli wiedzieć, jak radzi sobie misjonarz na placówce: „Pisuj do mnie przynajmniej co miesiąc, żebym wiedział regularnie, co się z Tobą dzieje, a zrobisz mi zawsze przyjemność, jeżeli przy tym pisaniu opowiesz mi i o duszy swojej, jak tam wewnątrz rzeczy stoją" ${ }^{56}$. Chociaż misjonarz podlegał bezpośrednio pod miejscowego hierarchę, który musiał wyrazić zgodę na jego obecnośćs $c^{57}$, generał zakonu czy biskup lub arcybiskup z miejsca, z którego pochodził misjonarz, wciąż mieli duży wpływ na działania danego misjonarza poprzez wskazówki i udzielane rady („Także już dawno chciałam zapytać Najdroższej Matuchny czy może tę kaplicę uważać za swoją. Zakładać pasy przy spowiedzi i podczas wystawienia, nie zapuszczać welonu i być bez płaszcza?" ${ }^{58}$ ). Ze względu na dzielącą ich odległość jedyną formą kontaktu była korespondencja, która miała charakter zarówno prywatny, jak i urzędowy, gdyż stanowiła własność nie tyle konkretnej osoby, ile zgromadzenia lub parafii.

\section{Źródła kościelne i ich wykorzystanie do badań nad chłopską emigracją}

Korespondencja misyjna stała się popularnym środkiem komunikacji nie tylko z przełożonymi, ale również z szerszym gronem odbiorców - wiernymi. Pisanie listów z „dalekich krajów” zostało zapożyczone przez duchownych z prasy świeckiej, która często zamieszczała zagraniczną korespondencję w postaci przedruku listów osób przebywających w jakimś egzotycznym miejscu. Taki sposób komunikacji z wiernymi szczególnie wykorzystywały czasopisma misyjne, na przykład miesięcznik „Missye Katolickie”, kwartalnik „Roczniki Obydwu Zgromadzeń św. Wincentego a Paulo” czy pierwsze czasopismo misyjne w Galicji „Rocznik Rozkrzewiania Wiary”" które w dużej części składały się z listów misjonarzy relacjonujących swoją pracę na placówkach zagranicznych. Korespondencje wydawano

55 Często się zdarza, że dysponujemy tylko fragmentami korespondencji, pojedynczym listem lub nawet tylko jego fragmentem.

56 List o. Piotra Semenenki do o. Michała Brzezińskiego, 23.01.1877, Studia Zmartwychwstańcze, t. 13: Listy o. Piotra Semenenki, red. J. D r o żd ż, Rzym 2008, s. 60.

57 List o. Piotra Semenenki do o. Władysława Witkowskiego, 10.10.1878, Studia Zmartwychwstańcze, t. 13, s. 159.

58 Archiwum Generalne Sióstr Felicjanek w Rzymie [dalej: AGSF], Korespondencja s. Leonardy Odrzywolskiej, 20.07.1903, sygn. 2173/903, s. 34 .

59 A. Kale ta, Rozwój polskiego czasopiśmiennictwa misyjnego do 1939 roku, „Rocznik Historii Prasy Polskiej” 1999, nr 2, z. 2, s. 7-10. 
również w formie książkowej. Przykładem są tu listy z Madagaskaru o. Jana Beyzyma ${ }^{60}$. Na potrzeby niniejszego artykułu możemy określić tego typu źródła epistolograficzne jako korespondencję „oficjalną”, gdyż listy były kierowane do druku i w tym celu były pisane. Danuta Lalak i Aneta Ostaszewska określiły ten rodzaj korespondencji jako list „publiczny”" . Autor źródła już na etapie tworzenia zdawał sobie bowiem sprawę z przyszłego upublicznienia jego listu, dlatego w zależności od tego, jaki efekt chciał uzyskać, informacje zawarte w liście mogły w jakiś sposób podlegać cenzurze (wprowadzonej przez samego autora lub redakcję). Niewykluczone, że specjalnie pomijał pewne fakty, inne zaś uwypuklał, chcąc tym samym uzyskać konkretną reakcję czytelników.

Czym innym jest więc korespondencja pisana z myślą o opublikowaniu jej, w celu dotarcia do szerszego grona odbiorców, a czym innym prywatny list kierowany do konkretnej osoby $^{62}$. Dlatego również korespondencję misyjną możemy podzielić na „oficjalną”, o której wspomniałem w powyższym akapicie, i „nieoficjalną”. Na korespondencję „nieoficjalną”, mającą prywatny charakter, skierowaną do konkretnej osoby możemy się natknąć, przeglądając spuściznę rękopiśmienną zgromadzeń misyjnych lub osób duchownych, które udały się z pracą duszpasterską do społeczności polonijnych.

Spuścizny duchownych stanowią ważny element zasobu archiwalnego - tyczy się to zarówno archiwów poszczególnych zgromadzeń ${ }^{63}$, jak i archiwów diecezjalnych ${ }^{64}$. Ma to związek i ze specyfiką życia duchownego, zwłaszcza zakonnego, i z długą tradycją gromadzenia materiałów archiwalnych przez instytucje kościelne ${ }^{65}$. Dlatego też świadomość duchownych o potrzebie zachowania materiałów dokumentujących ich działalność stała w XIX w. na wysokim poziomie. Dla zgromadzeń misyjnych korespondencja stanowiła też niejako dowód ich działalności, którą - jak wyżej wykazałem - chętnie wykorzystywano, co ma miejsce również i dzisiaj ${ }^{66}$. Dzięki temu stan zachowania tego typu źródeł jest niewspółmiernie lepszy niż w przypadku korespondencji innych osób mających związek z emigracją chłopską, jak sami chłopi czy też nielicznie występujący urzędnicy.

W swoich badaniach poddałem analizie korespondencję misyjną z kilku archiwów: Archiwum Prowincji Południowej Towarzystwa Jezusowego w Krakowie, Archiwum Generalnego

60 Zob. J. B e y z y m, Listy o. Jana Beyzyma T.J. apostota trędowatych na Madagaskarze, Kraków 1927.

${ }^{61}$ D. Lalak, A. Ostaszew ska, Źródta do badań biograficznych. Listy - Dzienniki - Pamiętnik - Blogi Materiaty Wizualne, Warszawa 2016, s. 28.

62 Ibidem, s. 31.

63 Zob. W. Mle c z ko, Catalogus Archivii Congregationis a Resurrectione DNJC, Rome 2013.

${ }^{64}$ H. Borcz, Struktura zasobu archiwów diecezjalnych w okresie nowożytnym (XIX i XX w.), „Archiwa, Biblioteki i Muzea Kościelne" 1998, t. 70, s. 25-43.

${ }_{65}$ R. Prejs, Organizacja i funkcjonowanie archiwów w domach zakonnych, „Archiwa, Biblioteki i Muzea Kościelne”, t. 75, 2001, s. 139-151.

66 Por. H. Kajsiewicz, Listy 1868-1869, t. 10, red. J. Drożd ż, Rzym 2012; P. S e men en ko, Listy, t. 15, red. J. Drożdż, Rzym 2011. 
Zgromadzenia Sióstr św. Feliksa w Rzymie, a także Archivio Congregazione della Risurrezione w Rzymie, gdzie znajduje się korespondencja zakonników ze zgromadzenia ojców zmartwychwstańców. Zebrany przeze mnie materiał źródłowy dotyczy nie tylko misji w dużych ośrodkach polonijnych w USA czy Brazylii, ale także w krajach, w których Polonia była dużo mniejsza, jak Bułgaria oraz Bośnia i Hercegowina. Kwerendę archiwalną uzupełniłem wydawnictwami źródłowymi: Studiami Zmartwychwstańczymi wydawanymi przez zakon ojców zmartwychwstańców. W sumie jest to około 400 listów. Wspomniane źródła obejmują misje, które miały miejsce we wspomnianych krajach na przełomie XIX i XX w. Celowo skupiłem uwagę na kilku zgromadzeniach i prowadzonych przez nie misjach w różnych zakątkach świata, by pokazać pewne możliwości wykorzystania wytworzonej przez ich członków korespondencji, bez względu na to, skąd listy pochodziły, a także kto był ich autorem. Sam fakt prowadzenia misji w konkretnym miejscu nie stanowi dla mnie problemu badawczego, gdyż nie analizuję ani przyczyn danej misji, ani jej skutków, a jedynie skupiam się na możliwościach metodologicznych, jakie daje list duchownego przebywającego na placówce misyjnej w odniesieniu do badań nad emigracją chłopską. Chcąc więc przedstawić użyteczność źródła, musiałem subiektywnie wybrać reprezentatywny materiał. Nie jest to więc zbiór listów stanowiących zwarty materiał źródłowy, jak w przypadku listów kierowanych do jakiejś instytucji, na przykład korespondencji do czasopisma „Po Prostu”, którą poddał badaniom Adam Leszczyński ${ }^{67}$.

Sądzę, że przeprowadzona kwerenda jest jednak na tyle szeroka, iż pozwala wskazać na pewne schematy występujące w tego typu korespondencji. Widząc możliwości, jakie daje opracowanie tegoż materiału, chciałbym spróbować stworzyć odpowiednią metodologię, którą można wykorzystać do badania całości tego typu materiału źródłowego w kontekście emigracji chłopskiej. Jest to o tyle interesujące, że korespondencja misjonarzy nie jest wyłącznie specyfiką polską, ale dotyczy również innych narodów, które prowadziły działalność misjonarską wśród swojego chłopstwa udającego się na emigrację. Można by więc w przyszłości pokusić się o podobne studia porównawcze w odniesieniu do innych narodowości.

Badając listy misjonarzy, zauważyłem, że istnieją pewne cechy wspólne dla tej korespondencji. Występują one bez względu na to, czy misjonarz pisał z farmy w USA czy też z brazylijskiej puszczy. Można więc, porównując ze sobą materiał z różnych części świata, podjąć próbę scharakteryzowania tego dokumentu, wskazania jego indywidualnych cech, a także zastanowienia się nad jego ewentualnym zastosowaniem. Korespondencja, nawet jeśli ma charakter informacyjny (gdzie przeprowadzono misje, ilu sakramentów i jakiego rodzaju udzielono ${ }^{68}$ ), jest kierowana do osoby dobrze znanej nadawcy, którą ten darzy

A. Leszczyński, Sprawy do zatatwienia. Listy do „Po Prostu” 1955-1957, Warszawa 2000.

68 Archiwum Prowincji Południowej Towarzystwa Jezusowego w Krakowie [dalej: ATJKr], Rkps, Korespondencja Misjonarzy z lat 1880-1914, list o. Antoniego Boca, 2.01.1913, sygn. 1316, s. 194. 
szacunkiem i sympatią. Mamy więc w nagłówku takie zwroty, jak: „Mój drogi, kochany Ojcze”,99, „Kochany mój ojcze Stachu”70, „Najprzewielebniejsza Najdroższa Matuchno nasza”71; najczęściej jednak spotykaną formą zwrotu do przełożonego było „Czcigodny Ojcze”72. Oczywiście zwroty te są formą grzecznościową, jednak ładunek emocjonalny, jaki im towarzyszy, świadczy o autentycznych uczuciach przyjaźni łączących nadawcę z adresatem listu. Można wobec tego oczekiwać szczerości intencji autora, co jednak nie musi oznaczać, że pisał on zawsze prawdę $e^{73}$.

Pierwszy list lub listy wysłane przez misjonarza lub misjonarkę po dotarciu na miejsce zawierają opis podróży i pierwsze wrażenia ${ }^{74}$. Te są najczęściej dość skrajne - od peanów ${ }^{75}$ aż po całkowitą krytykę ${ }^{76}$ miejsca i ludzi, wśród których przychodzi sprawować misję. Jeśli misjonarz pojawia się w miejscu zamieszkanym przez Polonię, gdzie wcześniej nie było polskiego duchownego, najczęściej witany jest bardzo serdecznie ${ }^{77}$. Chłopi niezwykle entuzjastycznie reagują na duchownego mówiącego w znanym im języku. Ich prostota pozwala sądzić, że reakcje te są spontaniczne i przede wszystkim szczere, gdyż rzeczywiście przywiązują oni ogromną wagę do sprawowania kultu w języku, który rozumieją. Chociaż ówczesna świadomość religijna chłopstwa była na ogół powierzchowna ${ }^{78}$, to jednak miała ona dla nich duże znaczenie, o czym już wyżej była mowa. Wracając jednak do samego schematu listu, to dodatkowo jeśli misjonarz przybywał ze współbraćmi lub współsiostrami w przypadku zakonnic, wówczas informował on także o ich stanie zdrowia i wrażeniach z podróży. „Tyle byłoby do napisania, że nie wiem od czego zacząć. Najlepiej od początku tj. od przybycia"79 - taka formuła pojawia się najczęściej, chociaż oczywiście może być ona wyartykułowana w różny sposób.

Kolejne listy, w zależności od zażyłości istniejącej między przełożonym a misjonarzem, stanowią rozwinięcie wątków poruszonych w pierwszych listach. Jest więc więcej

69 Ibidem, list. o. Antoniego Boca, 4.05.1905, s. 7.

70 Ibidem, list o. Jana Beigerta, 22.10.1904.

71 AGSF, Korespondencja s. Leonardy Odrzywolskiej, 25.03.1903, sygn. 2173/903, s. 1.

72 ATJKr, Rkps, Korespondencja Misjonarzy z lat 1880-1914, list o. Antoniego Boca, 30.11.1907, sygn. 1316, s. 71.

73 D. Lalak, A. Ostaszewska,op.cit., s. 24.

74 ATJKr, Rkps, Korespondencja Misjonarzy z lat 1880-1914, list o. Antoniego Boca, 30.03.1907, sygn. 1316, s. 26-27.

75 AGSF, Korespondencja s. Leonardy Odrzywolskiej, 24.05.1903, sygn. 2173/903, s. 3-4.

76 ATJKr, Rkps, Korespondencja Misjonarzy z lat 1880-1914, list o. Jana Beiglerta, 22.10.1904, sygn. 1316, s. 4.

77 AGSF, Korespondencja s. Leonardy Odrzywolskiej, 24.05.1903, sygn. 2173/903, s. 3-5.

78 D. Olszew ski, Polska kultura religijna na przetomie XIX i XX wieku, Warszawa 1996, s. 136-137.

79 AGSF, Korespondencja s. Leonardy Odrzywolskiej, 24.05.1903, sygn. 2173/903, s. 4. 
informacji o stanie duchowym wiernych, o ich gorliwości religijnej ${ }^{80}$. Jest to zatem podstawowy rekonesans mający uświadomić przełożonemu, z jakimi problemami będzie miał duchowny do czynienia w trakcie sprawowania misji w danym miejscu. W przypadku pobytu o. Stanisława Skwierawskiego, który trafił do wioski Miljevac w Bośni i Hercegowinie, zastąpił on skonfliktowanego z wiernymi o. Pawła Scheppego. Musiał więc przede wszystkim starać się o poprawę stosunków z wiernymi, co jednak nie do końca mu się udawało:

Teraz ci gałgani o ojcu Scheppe rozsiewają najgorsze oszczerstwa, tu tera o. Scheppego nie ma, więc bronić się nie może, ale ja myślę, że trzeba będzie zrobić coś z tymi łotrami, przecież Ojciec Paweł tutaj nie zasłużył, by szargano jego sławę - on zrobił bardzo wielką ofiarę ze siebie, siedząc tutaj tak długo, a przytem nadwyrężył bardzo swe zdrowie, i prawie fizycznie się zmarnował, tak że przy spotkaniu się z nim tutaj poznać go nie mogłem, a teraz za to wszystko mu się odpłacają kalumnami - Taki to nasz naród, dogodzić mu nikt nie potrafi ${ }^{81}$.

Znajdziemy również sporo informacji na temat sytuacji ekonomicznej i gospodarczej chłopów. Odnosi się to zarówno do kraju, w którym jest prowadzona misja, jak i do wioski, w której pracuje misjonarz ${ }^{82}$. Wiedza ta ma bezpośrednie przełożenie na podjęcie decyzji o rozpoczęciu lub kontynuowaniu budowy kościoła i budynków parafialnych ${ }^{83}$. Temat finansów poruszany jest zarówno wtedy, kiedy tyczy się misji trwających kilka bądź kilkanaście dni, jak i tych trwających latami. Można więc powiedzieć, że jest to ogólne sprawozdanie, które pozwala przełożonemu zorientować się w sytuacji, jaką zastał jego podwładny na miejscu. Uzyskuje więc tym samym najważniejsze informacje, które pozwalają na wstępne oszacowanie szans na powodzenie misji.

Korespondencja z przełożonym pełni jeszcze jedną ważną funkcję - pozwala zwierzchnikowi na pewnego rodzaju kontrolę nad podopiecznymi, dlatego misjonarze mieli w obowiązku zwracać się do generała zgromadzenia lub matki zakonnej z prośbą o pozwolenie na wszelkie działania, takie jak na przykład zmiana parafii ${ }^{84}$. Chociaż więc podlegali oni zwierzchnictwu lokalnej hierarchii, to jednak nic nie mogło się odbyć bez zgody prawowitego przełożonego.

${ }^{80}$ ATJKr, Rkps, Korespondencja Misjonarzy z lat 1880-1914, list o. Antoniego Boca, 30.11.1907, sygn. 1316, s. 76-78.

81 Archivio Congregazione della Risurrezione w Rzymie [dalej: ACRR], list Stanisława Skwierawskiego, 26.04.1915, sygn. 29681.

82 ATJKr, Rkps, Korespondencja Misjonarzy z lat 1880-1914, list o. Antoniego Boca, 30.03.1907, sygn. 1316, s. 31-33.

83 Burzliwe lata Polonii amerykańskiej. Wspomnienia i listy misjonarzy jezuickich 1864-1913, zebrał i oprac. L. Grzebień, Kraków 1983, s. 218.

${ }^{84}$ ACRR, list J. Wąchały-Zalesinskiego, 23.06.1914, sygn. 32566. 
O pierwszych poważnych problemach występujących na misji duchowny informował zazwyczaj dopiero po jakimś czasie (o ile te nie wystąpiły już na samym początku misji - pisałem powyżej o skrajnym podejściu do opisywanej rzeczywistości). Mogły to być różnorakie kłopoty. Najczęściej jednak dotyczyły one strony finansowej misjii ${ }^{85}$. Misjonarze bardzo często zwracali uwagę na fatalne warunki mieszkaniowe, a także żywieniowe. Ojciec Stanisław Skwierawski ze zgromadzenia zmartwychwstańców pisał do generała zakonu Jana Kasprzyckiego:

Tutaj w Miljevacu pomieszkanie mam bardzo nędzne, plebania to taka chata z gliny ulepiona, bez komina, bardzo niska, trochę wilgotna, już waląca się, a przy tem co najgorsze to w tej budzie pełno najrozmaitszego robactwa; są wielkie bardzo i obrzydliwe robaki, co po podłodze i ścianach łażą, i są małe dokuczliwe, które człowiekowi spokoju nie dają, nawet i przy jedzeniu muszę z nimi walkę staczać, bo mi do talerza włażą, a nieraz z sufitu wpadnie do talerza; nie wyobrażałem sobie, że to miejsce tutaj tak okropne ${ }^{86}$.

Misjonarze informowali także o innych problemach, takich jak konflikty z parafiana$\mathrm{mi}^{87}$ lub - w przypadku, gdy był więcej niż jeden misjonarz - wewnętrzne spory pomiędzy duchownymi ${ }^{88}$. Nieco rzadziej powodem narzekań kierowanych do przełożonego był problem z miejscowym zwierzchnikiem kościelnym ${ }^{89}$ bądź władzami świeckimi. W USA dużym problemem była szerząca się schizma wśród polskiego duchowieństwa. Działalność ks. Franciszka Hodura ${ }^{90} \mathrm{i}$ innych duchownych z Polskiego Narodowego Kościoła Katolickiego wprowadzały zamęt nie tylko wśród duchownych, ale również wiernych. W listach pisanych z misji w Stanach można spotkać się wielokrotnie z odniesieniami do tej kwestii ${ }^{11}$. Misjonarze zwracali uwagę na niechęć, jaka rodziła się w skonfliktowanej parafii, w której mieszkańcy dzielili się na zwolenników i przeciwników zbuntowanego księdza ${ }^{92}$.

Nie można też nie wspomnieć o aktywności na polu ewangelicznym, o której donosili duchowni. Żaden kapłan czy zakonnica nie zapominali o tym, by - czy to barwnymi opisami, czy statystykami - podkreślić swoje duszpasterskie sukcesy, dlatego dowiadujemy się o kulisach ewangelizacji, liczbie spowiedzi, chrztów itd. ${ }^{93}$ Często pojawiają się przy tej oka-

85 Studia Zmartwychwstańcze, t. 12: Listy o. Piotra Semenki, red. J. D rożdż, Rzym 2007, s. 78.

86 ACRR, list S. Skwierawskiego, 26.04.1915, sygn. 29681.

87 Ibidem.

88 ATJKr, Rkps, Korespondencja Misjonarzy z lat 1880-1914, list o. J. Belglerta, 2.07.1899, sygn. 1316, s. 2.

89 Czasem tego typu konflikty miały charakter narodowy. Por. T.J. L i s, op. cit., s. 129-131.

90 Zob. T.R. Maj e wski, Ks. Franciszek Hodur. Biskup, Polak, reformator, Warszawa 1966.

91 Burzliwe lata Polonii..., s. 60.

92 Ibidem.

93 ATJKr, Rkps, Korespondencja Misjonarzy z lat 1880-1914, list Aleksandra Mateucheka, 26.03.1901, sygn. 1316, s. 260. 
zji informacje o moralności parafian, ich stosunku do sakramentów, a także wypełnianiu nakazów religijnych w praktyce. Listy stanowią więc niejako formę autokreacji i sprawozdania z działalności księdza lub zakonnicy na placówce misyjnej. W przypadku tego pierwszego mamy często do czynienia z dokładnymi statystykami spowiedzi, wygłoszonych kazań, czasem również udzielonych sakramentów ${ }^{94}$. Jeśli chodzi zaś o zakonnice, tutaj sprawa ogranicza się głównie do ich sukcesów pedagogicznych, gdyż siostry, o ile nie pracowały w szpitalu, zajmowały się działalnością w szkole. Każdy jednak starał się podkreślić swoje zasługi i pokazać, jak jego obecność wpłynęła pozytywnie na społeczność, w której funkcjonował.

Można wobec tego pokusić się o metodologiczny schemat korespondencji pomiędzy osobą duchowną przebywającą na misji a jej przełożonym. Zaprezentowałem go w tabeli 1. Charakteryzuje on poszczególne części tego specyficznego źródła - zarówno jeśli chodzi o treść, jak i o informacje, jakie można z nich uzyskać. Poniższy schemat podzieliłem najpierw na etapy sprawowanej misji (od I do IV), by następnie przypisać im treść, z którą w poszczególnych etapach możemy się spotkać, a także informacje, jakie można uzyskać, analizując ten materiał w odniesieniu do chłopskiej emigracji.

Tabela 1. Schemat korespondencji misyjnej

\begin{tabular}{|c|c|c|}
\hline Etap & Treść & Informacje \\
\hline I. Początek & $\begin{array}{l}\text { Misjonarz opisuje podróź, samo- } \\
\text { poczucie swoje i osób, które mu to- } \\
\text { warzyszyły. Jest to etap dość krótki } \\
\text { i obejmuje od jednego do kilku listów } \\
\text { w przypadku obfitej koresponden- } \\
\text { cji lub też krótki ustęp w pierwszym } \\
\text { liście, jeśli mamy do czynienia z nie- } \\
\text { wielką ich liczbą. }\end{array}$ & $\begin{array}{l}\text { W przypadku zamorskiej emigracji } \\
\text { (Brazylia, USA) możemy dowiedziećć } \\
\text { się o warunkach panujących w czasie } \\
\text { podróży, a także o jej wpływie na sa- } \\
\text { mopoczucie podróżujących, ponadto } \\
\text { o trasie, odżywianiu, czasie trwania } \\
\text { podróży, motywach wyjazdów itp. }\end{array}$ \\
\hline II. Rekonesans & $\begin{array}{l}\text { Misjonarz opisuje religijność miesz- } \\
\text { kańców, ocenia ich położenie ekono- } \\
\text { miczne. Opis ten jest obszerniejszy } \\
\text { niż ten dotyczący wcześniejszego } \\
\text { etapu. Może on pojawić się po kilku } \\
\text { dniach i trwać do miesiąca, w zależ- } \\
\text { ności od tego, jak długo trwała misja. }\end{array}$ & $\begin{array}{l}\text { Możemy się dowiedzieć o świadomo- } \\
\text { ści religijnej chłopów, postępującej } \\
\text { laicyzacji i zmianach mentalnych, } \\
\text { jakie dokonywały się wśród chłopów } \\
\text { na emigracji. Ponadto informacje } \\
\text { o ich zamożności to doskonały mate- } \\
\text { riał zarówno dla osób zajmujących się } \\
\text { historią gospodarczą, jak i społeczná. } \\
\text { Możemy też porównać poszczegól- } \\
\text { ne placówki misyjne pod kątem ich } \\
\text { finansów. }\end{array}$ \\
\hline
\end{tabular}

94 ATJKr, Rkps, Korespondencja Misjonarzy z lat 1880-1914, wykaz dołączony do listu o. Antoniego Boca, 2.01.1913, sygn. 1316, s. 194. 


\begin{tabular}{|c|c|c|}
\hline Etap & Treść & Informacje \\
\hline III. Problemy misji & $\begin{array}{l}\text { Na tym etapie duchowny informu- } \\
\text { je o problemach misji, zarówno jeśli } \\
\text { chodzi o jej stronę materialną, jak } \\
\text { i stosunki z wiernymi. Ma to miejsce } \\
\text { najczesściej na kilka tygodni po przy- } \\
\text { byciu duchownego. Informacje o pro- } \\
\text { blemach mogą pojawiać się w kore- } \\
\text { spondencji aż do zakończenia misji. }\end{array}$ & $\begin{array}{l}\text { Wejście w głębsze relacje z wiernymi } \\
\text { pozwala duchownemu lepiej ich po- } \\
\text { znać. Dowiadujemy się dzięki temu } \\
\text { bardzo wiele o życiu codziennym } \\
\text { chłopów, ich świadomości narodo- } \\
\text { wej, tęsknocie za miejscem, w którym } \\
\text { wcześniej mieszkali, problemach ro- } \\
\text { dzinnych, zmianach, jakie dokonały } \\
\text { się u nich za sprawą emigracji, sto- } \\
\text { sunku chłopów do kraju, do którego } \\
\text { wyemigrowali. }\end{array}$ \\
\hline IV. Działalność & $\begin{array}{l}\text { Ostatni etap dotyczy działalności mi- } \\
\text { sjonarza, jego sukcesów (najczęściej) } \\
\text { i porażek (nieco rzadziej). Opis po- } \\
\text { wyższych działań trwa aż do zakoń- } \\
\text { czenia misji. }\end{array}$ & $\begin{array}{l}\text { Widzimy, jakie działania podejmu- } \\
\text { je duchowny (może to być pomoc } \\
\text { w udzielaniu sakramentów lub budo- } \\
\text { wie kościoła), a także jaki to ma, jego } \\
\text { zdaniem, efekt. Misjonarz prezentuje } \\
\text { zmiany dokonujące się na placówce } \\
\text { misyjnej za sprawą jego działalności. } \\
\text { Jest to najbardziej subiektywna część } \\
\text { relacji, z jaką mamy do czynienia } \\
\text { w opisywanej korespondencji, gdyż } \\
\text { większość duchownych stara się pod- } \\
\text { kreślić swoje duszpasterskie zaangażo- } \\
\text { wanie i sukcesy, które za tym idą. }\end{array}$ \\
\hline
\end{tabular}

Poza powyższymi wnioskami należy również poświęcić uwagę scharakteryzowaniu osoby autora listu95. Czy jest to wykształcony, doświadczony duchowny, czy może przeciwnie - młody, niedoświadczony ksiądz lub zakonnik? Jak to się stało, że znalazł się na misji ? Zgłosił się sam lub też został skierowany na placówkę bez pytania go o opinię w tej sprawie? Każda, nawet - wydawałoby się - najmniej istotna informacja, może okazać się kluczowa, jeśli chodzi o badania nad korespondencją.

Gdy już uda się ustalić odpowiednie informacje o twórcy źródła, należy przejść do samego źródła. W przypadku korespondencji istotna jest liczba listów, a także stan ich zachowania (to, czy posiadamy wszystkie listy wraz z odpowiedziami albo tylko część). By upewnić się co do tego, czy takowa korespondencja w ogóle istnieje, należy przeprowadzić kwerendę najpierw w archiwum danego zgromadzenia (jeśli misjonarzem jest zakonnik), a następnie w domu generalnym zakonu, do którego należał dany misjonarz. Najbardziej komfortowa jest sytuacja, gdy mamy do czynienia z pełną korespondencją - i przychodzącą, i wychodzącą. Wówczas, jeśli korespondencja z misji liczy sobie kilkadziesiąt lub kilkaset listów wraz z odpowiedziami, możemy odtworzyć dokładnie jej przebieg, oczywiście

95 S. Skwarczyńska, op.cit., s. 93. 
posiłkując się możliwie największą liczbą innych materiałów, które pozwolą nam zweryfikować podane przez autorów informacje.

Znaczna część korespondencji dotyczy wiernych: ich problemów, nie tylko duchowych, ale również bardziej przyziemnych, jak niedostatek ${ }^{96}$, tęsknota za bliskimi, procesy adaptacyjne i akulturacyjne itp. Niektóre korespondencje misyjne dostarczają bardzo szczegółowych informacji na temat działalności misjonarzy. Przykładowo korespondencja między felicjankami s. Leonardą Odrzywolską a matką generalną Magdaleną Borowską, licząca łącznie kilkaset listów, stanowi główne źródło do poznania życia i obyczajów pierwszego pokolenia polskich kolonistów osadzonych w Bośni i Hercegowinie ${ }^{97}$.

Źródła osobiste wytworzone przez duchownych, oprócz wyżej wymienionych zalet, są wyjątkowe również ze względu na rolę, jaką ich twórca - misjonarz - odgrywał wśród wiernych. Księża (nieco mniej zakonnice) często byli nie tylko przewodnikami duchowymi, ale także autentycznymi przywódcami lokalnej wspólnoty. Przywódcami politycznymi i narodowymi, gdyż spory wewnątrz społeczności polskiej na emigracji również nie należały do rzadkości ${ }^{98}$. Jako osoby najlepiej wykształcone i cieszące się powszechnym autorytetem brali aktywny udział w życiu całej wspólnoty. Bez względu na to, czy misja została założona w Brazylii, USA czy którymś z krajów europejskich, duchowni odgrywali kluczową rolę wśród społeczności, w której przyszło im pełnić posługę kapłańską ${ }^{99}$. Henryk Sienkiewicz w czasie swojej podróży po Ameryce wspominał, że tam w polskich osadach „władza świecka spoczywała w rękach duchownych” ${ }^{100}$. Duchowni byli więc centralnymi postaciami, stąd ich obserwacje dotyczą nie tylko punktu widzenia jednej osoby, jak ma to miejsce w nielicznych źródłach chłopskich, ale całej lokalnej społeczności. Choć oczywiście zawsze należy mieć na uwadze, że jak każde źródło narracyjne, także i to cechuje się daleko posuniętym subiektywizmem.

Stosunkowo częstym problemem poruszanym w korespondencji i pamiętnikarstwie misjonarzy pracujących wśród Polonii były konflikty między duszpasterzem a wiernymi, które wywiązywały się po kilkumiesięcznym pobycie duchownego na placówce. Spory tego typu na ogół kończyły się opuszczeniem parafii przez skonfliktowanego księdza. Wówczas sprowadzano nowego duchownego, którego zadaniem było uporządkowanie spraw parafii i przywrócenie w niej harmonii ${ }^{101}$, gdyż brak odpowiednio szybkiej reakcji mógł mieć bardzo przykre konsekwencje dla całej wspólnoty.

\footnotetext{
96 ATJKr, Rkps, Korespondencja Misjonarzy z lat 1880-1914, list o. Aleksandra Mateuscheka, 22.09.1880, sygn. 1316, s. 225-226.

97 T.J. Lis, op. cit., s. 182-183.

98 Burzliwe lata Polonii..., s. 122.

99 J. Mazurek, Kraj a emigracja, s. 79.

100 H. Si n kiew ic z, Listy z podróży do Ameryki, t. 2, Warszawa 1950, s. 274-275.

101 Burzliwe lata Polonii..., s. 30.
} 
Konkludując, narracyjne źródła kościelne stanowią integralną część materiału, jaki należy wykorzystać do pracy nad historią wychodźstwa chłopskiego. Tyczy się to zarówno emigracji zamorskiej, jak i kontynentalnej. Dzięki stanowi zachowania, a także bogactwu informacji jest to materiał mogący być często jedynym źródłem osobistym, które udaje się ustalić w celu wykorzystania go do poznania historii jakiegoś konkretnego wydarzenia. Warto więc, zajmując się historią emigracji chłopskiej, zajrzeć do archiwów kościelnych. Wizyta w takim miejscu z pewnością okaże się owocna i pozwoli ustalić badaczowi niejeden dodatkowy szczegół, niekoniecznie związany ze sprawami religii czy Kościoła, ale często spraw całkowicie świeckich. Materiał ten powinien przykuć uwagę nie tylko historyków, ale także przedstawicieli innych dyscyplin naukowych, z socjologami na czele.

Co więcej, powyżej przedstawione ustalenia można odnieść do chłopów katolików z innych krajów, którzy opuszczali swoje domy i wędrowali „za chlebem”. Tyczy się to więc przede wszystkim XIX-wiecznej emigracji z terenów Austro-Węgier, gdyż to stamtąd rekrutowało się najwięcej takich osób. Być może komparatystyczne badania nad wychodźstwem z terenów monarchii habsburskiej na podstawie kościelnych źródeł narracyjnych pozwoliłyby znaleźć nowe perspektywy w tym temacie. $Z$ pewnością kierunek ten jest interesujący i może przynieść wiele korzyści naukom humanistycznym nie tylko polskim, ale także w innych krajach.

\section{WYBRANA BIBLIOGRAFIA}

\section{Źródła archiwalne:}

Archivio Congregazione della Risurrezione w Rzymie, Listy Zmartwychwstańców.

Archiwum Generalne Sióstr Felicjanek w Rzymie, Korespondencja s. Leonardy Odrzywolskiej.

Archiwum Kurii Metropolitalnej w Krakowie, Teki Sapieżyńskie.

Archiwum Prowincji Południowej Towarzystwa Jezusowego w Krakowie, Korespondencja Misjonarzy.

\section{Opracowania:}

Baczko B., Pisać listy z Hameryki, „Zeszyty Historyczne” 1982, t. 61 s. 51-67.

Baczkowski M., Analfabetyzm w Galicji w dobie konstytucyjnej, [w:] Naród - Państwo. Europa Środkowa w XIX i XX wieku. Studia ofiarowane Michatowi Putaskiemu w pięćdziesięciolecie pracy naukowej, red. A. Patek, W. Rojek, Kraków 2006, s. 97-113.

Bakalarz J., Polskie modlitewniki na emigracji, „Studia Polonijne” 1981, t. 4, s. 213-227.

Banach A.K., Kariery zawodowe studentów Uniwersytetu Jagiellońskiego pochodzenia chtopskiego z lat 1860/61-1917/18, Kraków 2009.

Borcz H., Struktura zasobu archiwów diecezjalnych w okresie nowożytnym (XIX i XX w.), „Archiwa, Biblioteki i Muzea Kościelne" 1998, t. 70, s. 25-44.

Brodowska-Kubicz H., $Z$ listów chtopów emigrantów, „Annales Universitstis Mariae Curie-Skłodowska. Sectio K. Politologia" 1999, t. 6, s. 95-106. 
Broński K., Problem zacofania gospodarczego Galicji. Mity i fakty, [w:] Historia gospodarcza i historia myśli ekonomicznej a teoria ekonomii. Problemy metodologiczne, red. J. Skodlarski, Łódź 2008, s. 67-82.

Brożek A., Listy emigrantów jako źródto w tradycji i wspótczesności polskich nauk spotecznych, [w:] Dziedzictwo Witolda Kuli, Warszawa 1990, s. 31-63.

Burzliwe lata Polonii amerykańskiej. Wspomnienia i listy misjonarzy jezuickich 1864-1913, zebrat i oprac. L. Grzebień, Kraków 1983.

Dmowski R., Z Parany, „Przegląd Wszechpolski”, nr 2, s. 109-121; nr 3, s. 172-182; nr 6, s. 359-375.

Dunin-Wąsowicz K., Świadomość narodowa chtopów w świetle pamiętników w okresie powstań narodowowyzwoleńczych, „Acta Universitatis Lodziensis - Folia Historica” 1992, nr 45, s. 87-93.

Dworecki T., Zmagania polonijne w Brazylii, t. 1: Polscy werbiści 1900-1978, Warszawa 1980.

Gajewski K., $Z$ poetyki listu chtopskiego do wtadzy. Od stalinizmu do matej stabilizacji, „Rocznik Antropologii Historii" 2016, nr 9, s. 205-228.

Jankowska H., Spustek J., Wychodźstwo polskie w Stanach Zjednoczonych, [w:] Pamiętniki emigrantów, t. 1: Stany Zjednoczone, red. J. Dziembowska, Warszawa 1977.

Jaszczyńska M., Korespondencja emigrantów jako źródto do badań nad dziejami emigracji, [w:] Emigracja i środowiska polonijne. Archiwa i archiwalia, red. A. Kulecka, Warszawa 2013, s. 35-49.

Jaśkiewicz B., Dziatalność Towarzystw Oświatowych w Tarnowie w latach autonomii galicyjskiej, „Rozprawy z Dziejów Oświaty” 1974, t. 17, s. 105-142.

Kaleta A., Rozwój polskiego czasopiśmiennictwa misyjnego do 1939 roku, „Rocznik Historii Prasy Polskiej” 1999, nr 2, z. 2, s. 5-24.

Kieniewicz S., Listy, które nie doszty do celu, „Nowe Książki” 1974, nr 24, s. 31.

Kościałkowski S., Historyka - wstęp do studiów historycznych, Londyn 1954.

Krakowski S., List jako źródto historyczne: uwagi w sprawie definicji i kategoryzacji, „Sprawozdania z Czynności i Posiedzeń Naukowych Łódzkiego Towarzystwa Naukowego” R. 40, 1986, nr 8, s. 1-8.

Kula W., Assorodobraj-Kula N., Kula M., Listy emigrantów z Brazylii i Stanów Zjednoczonych 1890-1891, Warszawa 1973.

Lalak D., Ostaszewska A., Źródta do badań biograficznych. Listy - Dzienniki - Pamiętniki - BlogiMateriaty Wizualne, Warszawa 2016.

Lange A., Analfabetyzm i walka z ciemnotą w Królestwie Polskim, Warszawa 1906.

Lis T.J., Polskie osadnictwo i duchowieństwo w Bośni i Hercegowinie od 1894 do 1920 roku, Toruń 2014.

Listy z Brazylii Adolfa Dygasińskiego, specjalnego delegata „Kuriera Warszawskiego”, Warszawa 1891.

Listy z Brazylii przez wychodźców do rodzin pisane, red. A. Potocki, Warszawa 1891.

Ludność Galicji, „Ekonomista” 1881, nr 46, s. 9-10 (3 XI).

Malczewski Z., W trosce nie tylko o rodaków. Polscy misjonarze w Brazylii, Curtiba 2001.

Mazurek J., Kraj a emigracja, Warszawa 2006.

Mazurek J., Piórem i czynem. Kazimierz Warchatowski (1872-1943) - pionier osadnictwa polskiego w Brazylii i Peru, Warszawa 2013.

Michalik-Sztumska M., Wychodźstwo polskie w Brazylii. Stan badań nad zagadnieniem, „Prace Naukowe Akademii im. Jana Długosza w Częstochowie. Zeszyty Historyczne” 2010, z. 11, s. 323-330.

Missye polskie w Ameryce, „Missye Katolickie”, R. 2, 1883, nr 9, s. 234-246.

Mleczko W., Catalogus Archivii Congregationis a Resurrectione DNJC, Rome 2013. 
Mlekodaj A., Wieś i gwara w dobie rekonfiguracji kultury (na przyktadzie Podhala), „Wieś i Gwara” 2016, t. 8, s. 17-22.

Olszewski D., Polska kultura religijna na przetomie XIX i XX wieku, Warszawa 1996.

Piech S., Duchowieństwo a masowe migracje zarobkowe w diecezji tarnowskiej 1876-1914, „Chrześcijanin w Świecie” R. 16, 1984, nr 2, s. 48-66.

Pilch A., Emigracja z ziem zaboru austriackiego (odpotowy XIX w. do 1918 r.), [w:] Emigracja zziem polskich w czasach nowożytnych i najnowszych, red. idem, Warszawa 1984, s. 252-325.

Praszałowicz D., Makowski K.A., Zięba A.A., Mechanizmy zamorskich migracji tańcuchowych w XIX wieku: Polacy, Niemcy, Żydzi, Rusini - zarys problemu, Kraków 2004.

Prejs R., Organizacja i funkcjonowanie archiwów w domach zakonnych, „Archiwa, Biblioteki i Muzea Kościelne" 2001, t. 75, s. 45-59.

Römer E., Rocznik Polski. Tablice statystyczne, Kraków 1917.

Sienkiewicz H., Listy z podróży do Ameryki, t. 2, Warszawa 1950.

Skwarczyńska S., Teoria listu, Białystok 2006.

Studia Zmartwychwstańcze, t. 12: Listy o. Piotra Semenki, red. J. Drożdż, Rzym 2007.

Studia Zmartwychwstańcze, t. 13: Listy o. Piotra Semenenki, red. J. Drożdż, Rzym 2008.

Szatur-Jaworska B., Analiza pamiętników jako metoda badawcza w nauce o polityce spotecznej, „Problemy Polityki Społecznej. Studia i Dyskusje” 2001, nr 3, s. 83-94.

Szturm de Sztrem T., Instytut Gospodarstwa Spotecznego 1920-1944, Warszawa 1959.

Śliwa M., Nędza galicyjska. Mit i rzeczywistość, [w:] Galicja i jej dziedzictwo, t. 1: Historia i polityka, red. W. Bonusiak, J. Buszko, Rzeszów 1994, s. 145-155.

Taras P., Problemy duszpasterstwa polonijnego na przyktadzie sytuacji w USA, „Studia Polonijne” 1977 , t. 2, s. 181-205.

Thomas W., Znaniecki F., Chtop polski w Europie i Ameryce, t. 1, Warszawa 1976.

Walewander E., Duszpasterstwo polskie w Ameryce Eacińskiej. Przyczynek do bibliografii, [w:] Rola duszpasterstwa polskiego w organizacji spoteczności lokalnych w Ameryce Eacińskiej, red. M. Malinowski, Warszawa 1999, s. 119-130.

Woś M., Salezjański system wychowania a socjologia wychowania Floriana Znanieckiego, „Seminarae” 2015, nr 21, s. 531-546. 